\title{
Cytokines in crevicular fluid and orthodontic force: a systematic review
}

\author{
Susiane Allgayer ${ }^{\mathrm{a}}$, Luciane Macedo de Menezes ${ }^{\mathrm{b}}$, Mariana Roennau Lemos Rinaldi ${ }^{\mathrm{c}}$
}

\begin{abstract}
OBJECTIVE: This paper aimed to analyze studies in the literature addressing the role of cytokines in the gingival crevicular fluid (GCF) in the orthodontic treatment.

METHODS: Several databases were surveyed using both MESH terms and free terms. Additional studies were obtained by reference tracking. This review was registered in PROSPERO, and the procedures foreseen by its statement were followed. Data were obtained from the included studies addressing the orthodontic mechanics, GCF sampling/handling methods, and cytokine measurements. Clinical studies written in English were browsed. Papers were selected by one reviewer and checked by a second investigator.

RESULTS: A total of 115 articles were identified, among which 25 were selected for detailed analysis. Common drawbacks consisted mainly of inadequacies in the study design (e.g. short duration and small number of study subjects). The most consistent result was a peak of cytokine levels at $1 \mathrm{~d}$. Associations were observed between prostaglandin E2 (PGE2) and interleukin-1 $\beta$ (IL-1 $\beta$ ) and pain, velocity of tooth movement, and treatment mechanics. Interleukin-1b and PGE2 showed different patterns of up-regulation, with IL-1 $\beta$ being more responsive to mechanical stress and PGE2 more responsive to synergistic regulation of $\mathrm{IL}-1 \beta$ and mechanical force. The results support the use of light continuous forces for orthodontic treatment.

CONCLUSION: There was a tendency of maintenance of relatively high IL-1 $\beta$ levels for longer periods with the use of light continuous forces, which might decrease the frequency of activation. These outcomes provide evidence at the cellular level for the utilization of light continuous forces.
\end{abstract}

Key words: Systematic review; Orthodontics, corrective; Gingival Crevicular Fluid (GCF); Interleukin; T Cells.

\section{Papel das citocinas presentes no fluido crevicular durante o tratamento ortodôntico: uma revisão sistemática}

\section{RESUMO}

OBJETIVO: Este artigo teve como objetivo analisar estudos na literatura abordando o papel das citocinas no Líquido do Sulco Gengival no tratamento ortodôntico.

MÉTODOS: Várias bases de dados foram pesquisadas usando termos MESH e termos livres. Estudos adicionais foram obtidos por rastreamento de referência. Esta revisão foi registrada no PROSPERO, e os procedimentos previstos por sua declaração foram seguidos. Os dados foram obtidos dos estudos incluídos sobre a mecânica ortodôntica, métodos de amostragem / manuseio de Líquido do Sulco Gengival e medições de citoquinas. Estudos clínicos escritos em inglês foram pesquisados. Os trabalhos foram selecionados por um revisor e verificados por um segundo investigador

RESULTADOS: Foram identificados 115 artigos, dentre os quais 25 foram selecionados para análise detalhada. As desvantagens comuns consistiram principalmente em insuficiências no design do estudo (por exemplo, curta duração e pequeno número de sujeitos do estudo). O resultado mais consistente foi um pico de níveis

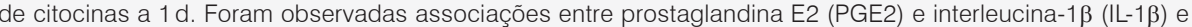
dor, velocidade do movimento dentário e mecânica de tratamento. A interleucina-1 $\beta$ e a PGE2 apresentaram diferentes padrões de regulação ascendente, sendo IL-1 $\beta$ mais sensível ao estresse mecânico e PGE2 mais responsivo à regulação sinérgica da IL-1 $\beta$ e força mecânica. Os resultados suportam o uso de forças contínuas leves para tratamento ortodôntico.

CONCLUSÃO: Houve uma tendência de manutenção de níveis relativamente altos de IL-1 $\beta$ por períodos mais longos com o uso de forças contínuas leves, o que pode diminuir a freqüência de ativação. Esses resultados fornecem evidências no nível celular para a utilização de forças contínuas leves.

Palavras-chave: Revisão sistemática; Ortodontia corretiva; Líquido do sulco gengival; Interleucina; Célula T a Professor, Department of Orthodontics, ABORS Associação Brasileira de Odontologia - Seção Rio Grande do Sul, Porto Alegre, Brazil

b Professor, Department of Orthodontics, Pontifical Catholic University of Rio Grande do Sul, Porto Alegre, Rio Grande do Sul, Brazil

PhD Student, Department of Orthodontics, Pontifícia Universidade Católica do Rio Grande do Sul (PUCRS), Porto Alegre, RS, Brazil 


\section{INTRODUCTION}

Orthodontic tooth movement may be achieved by application of forces on the periodontal ligament (PDL) and by alveolar bone remodeling. The mechanical stimuli applied on teeth provoke inflammatory responses in periodontal tissues, with release of inflammatory mediators, inducing the biological processes that promote alveolar bone resorption and apposition [1-7].

Analysis of constituents of the gingival crevicular fluid (GCF) may reveal quantitative biochemical indicators of the local cellular metabolism, which reflect the periodontal health status and bone remodeling promoted by orthodontic treatment [7-9]. Recently, the expression of regulatory proteins in GCF has been regarded as an important diagnostic marker for follow-up of orthodontic treatment outcomes. Most studies have been addressing new mediators and upand down-regulation of these protein levels in different treatments. However, limited information is available from studies on the relationship between orthodontic tooth movement and regulatory proteins in GCF $[2,3,9]$.

Among several regulatory proteins detected in GCF, this review will focus on cytokines. Cytokines are key mediators involved in initiating, amplifying, perpetuating, and resolving inflammatory responses $[1,7]$. The actions of cytokines include several effects on immune cells and modulation of inflammatory responses $[10,11]$. The cytokines are produced by cells in the periodontal tissue as fibroblasts and osteoblasts, and they participate in normal physiological bone turnover and remodeling [11-17]. Many characteristics of these cytokines are of interest in orthodontics, since cytokines in the GCF reflect the microenvironment of periodontal tissues, in which orthodontic forces are applied $[2,4,15]$. Several studies also revealed that cytokines are fundamental in cell signaling in bone $[14,18,19]$ and in mediating mechanically induced bone remodeling (e.g. by orthodontic forces) $[1,2,20]$.

In addition, several narrative reviews have extensively illustrated the involvement of regulatory proteins in periodontal remodeling promoted by orthodontic stimuli $[1$, $2,4,6]$, but little effort has been made to systematically investigate the time-related regulations and production mechanisms of these regulatory proteins stimulated by mechanical stress. Thus, this systematic review aimed to analyze studies on cytokine expression in the GCF during orthodontic treatment, evaluating the regulation patterns of cytokines over time and addressing their clinical implications. Even though some aspects deserve further analyses, there are still questions on whether there might be associations between cytokines in GCF and tooth movement, as well as on the timerelated regulation pattern of cytokine production in GCF, which could guide the clinical protocols at the cellular level.

\section{METHODS}

This review was conducted according to the QUOROM statement suggestions [21] and registered in PROSPERO on 20 November, 2014 (registration No. CRD42014015048).
The systematic review was conducted strictly adhering to the guidelines suggested by PROSPERO. Several key databases (MEDLINE, PubMed, Embase, Cochrane library, Web of Science) were searched in May 2014 using the MESH terms "Orthodontics, Corrective", "Interleukin-17", or "helper T Cells", or "helper 17 cell", or "TH 17", "IL 17", "Interleukin-23", "IL 23", “crevicular fluid", and using the free text terms "GCF, gingival crevicular fluid, cytokines, inflammatory factors, regulatory proteins, tooth displacement, canine distalization, and root resorption". An additional search was performed by reference tracking. The search results from each database were combined. Duplicate results were eliminated (Table 1). The inclusion criteria were: human studies on GCF, articles written in English, cytokines (including prostaglandins E2 (PGE2), tumor necrosis factor (TNF), interleukins, growth factor, osteoprotegerin (OPG) and RANKL) or their receptors as study mediators, orthodontic mechanics, GCF sampling, cytokine measurements, number of study subjects $\geq 5$ or number of study teeth $\geq 10$, proper oral hygiene control, no use of antibiotic/anti-inflammatory drugs before tooth movement and GCF sampling. The exclusion criteria were: animal studies, in vitro studies, narrative reviews, expert reviews (non-systematic reviews), and studies on human GCF enzymes or any metabolic products other than mentioned in the inclusion criteria.

The selection of articles was performed by one reviewer and checked by a second investigator. The titles and abstracts of potentially relevant articles were analyzed before full-text analysis. From each study that remained after application of the inclusion criteria, data were extracted in three categories, as follows.

1. Orthodontic mechanics: number of study subjects, tooth and treatment mechanics (appliances) studied.

2. GCF sampling methods: sampling methods (paper strips), cytokine measurements, duration of the study and number of samples.

3. Cytokine measurements: peak levels.

\section{RESULTS}

The review identified 115 potentially relevant studies. Table 1 presents an overview of the outcomes. Among these studies, further analysis of the titles, abstracts, and fulltexts revealed that 25 were relevant for the present study. A summary of papers that were excluded is presented in Figure 1 (exhibiting the orthodontic mechanics, GCF sampling methods, and cytokine measurements) [1-6,22-41].

Most studies were performed on mixed samples of adolescents and young adults, and two studies reported the levels of GCF cytokines in different age groups (Table 1). Only three studies included more than 20 subjects. Seventeen out of 25 studies used the maxillary canine as the study tooth, and the force system was distalization with either sectional wires or continuous arch wires. The other eight studies addressed aligning movement (three), insertion of separation elastics (two), Hyrax appliance (two) and cervical headgear (one). 
Table 1. Studies assessing cytokines in gingival crevicular fluid (GCF) in orthodontics.

\begin{tabular}{|c|c|c|c|c|c|c|}
\hline Reference / Article & $\begin{array}{l}\text { Sample (n) } \\
\text { Age (yr) }\end{array}$ & Sampling (points) & Method & Cytokine & Peak & Results \\
\hline [41] Alikhani et al 2014 & $\begin{array}{c}20 \\
19.5-33.1\end{array}$ & $0,24 h, 28 d$ & Canine distalization & $\begin{array}{l}\text { IL-1 } 1 \beta \text {, } \\
\text { IL-1 } \alpha \text {, } \\
\text { IL-6, } \\
\text { IL- 8, } \\
\text { TNF, } \\
\text { MCP-1 }\end{array}$ & & Tend to increase \\
\hline [40] Enhos et al 2014 & $\begin{array}{c}20 \\
18+-3\end{array}$ & $0,24,48,168 h, 30 d$ & Canine distalization & $\begin{array}{l}\text { RANKL } \\
\text { OPG }\end{array}$ & & $\begin{array}{l}\text { OPG and RANKL levels vary as } \\
\text { a result of force application }\end{array}$ \\
\hline [38] Gastel et al 2011 & $\begin{array}{c}24 \\
14+-1\end{array}$ & $0,365 d$ & Headgear & $\begin{array}{l}\text { IL-2 } \\
\text { IL-4 } \\
\text { IL-6 } \\
\text { IL-8 } \\
\text { IL-10 } \\
\text { GM-CSF } \\
\text { INF } \\
\text { TNF } \\
\text { MCP-1 } \\
\text { IP-10 }\end{array}$ & & $\begin{array}{l}\text { No significant alteration } \\
\text { No significant alteration } \\
\text { Tend to increase } \\
\text { Tend to increase } \\
\text { No significant alteration } \\
\text { No significant alteration } \\
\text { No significant alteration } \\
\text { No significant alteration } \\
\text { No significant alteration } \\
\text { No significant alteration }\end{array}$ \\
\hline [3] Tzannetou 2008 & $\begin{array}{c}9 \\
10-18\end{array}$ & $0,24 h, 7 d, 14 d, 21 d$ & Hyrax RME & $\mathrm{IL}-1 \beta$ & & $\begin{array}{l}\text { Increased during active RME; } \\
\text { remained high in retention phase }\end{array}$ \\
\hline [22] Karacay et al 2007 & $\begin{array}{c}10 \\
15+-1\end{array}$ & $0,1,24,168 \mathrm{~h}$ & Canine distalization & TNF- $\alpha$ & $1 d$ & $\begin{array}{l}\text { Hybrid: no change with time } \\
\text { Distraction: higher than hybrid }\end{array}$ \\
\hline [23] Iwasaki 2006 & $\begin{array}{c}10 \\
15+-4\end{array}$ & $\begin{array}{c}0,1,3,7,14,28,42 \\
56,70,84 d\end{array}$ & Canine distalization & $\begin{array}{l}\text { IL-1 } 1 \beta \\
\text { IL-1ra }\end{array}$ & & $\begin{array}{l}\text { Tooth movement rate relate to } \\
\text { IL-1 gene polymorphisms }\end{array}$ \\
\hline [4] Dudic 2006 & $\begin{array}{c}18 \\
9-14\end{array}$ & $\begin{array}{l}-7 d, 0,1 \min , 1 \mathrm{~h} \\
1 \mathrm{~d}, 7 \mathrm{~d}\end{array}$ & Separation elastics & $\begin{array}{l}\text { IL-1 } \beta \\
\mathrm{PGE}_{2} \\
\mathrm{SP}\end{array}$ & $\begin{array}{l}1 d \\
1 d \\
1 d\end{array}$ & $\begin{array}{l}\text { Higher levels at tension sites } \\
\text { Higher levels at tension sites }\end{array}$ \\
\hline [24] Basaran 2006 & $\begin{array}{c}18 \\
16-19\end{array}$ & $\begin{array}{c}0,7 d, 21 d, 6 m n s \\
+7 d,+21 d\end{array}$ & Canine distalization & $\begin{array}{l}\text { IL-1 } 1 \beta \\
\text { TNF- } \alpha\end{array}$ & & $\begin{array}{l}\text { Tend to increase } \\
\text { Tend to increase }\end{array}$ \\
\hline [25] Kawasaki 2006 & $\begin{array}{c}15 \\
15+-3 \\
15 \\
31+-4\end{array}$ & $0,1,24,168 \mathrm{~h}$ & Canine distalization & $\begin{array}{l}\text { RANKL } \\
\text { OPG }\end{array}$ & $\begin{array}{l}1 d \\
1 d\end{array}$ & $\begin{array}{l}\text { Lower ratio in adults } \\
\text { Lower ratio in adults }\end{array}$ \\
\hline [26] Nishijima 2006 & $\begin{array}{c}10 \\
15+-2\end{array}$ & $0,1,24,168 \mathrm{~h}$ & Canine distalization & $\begin{array}{l}\text { RANKL } \\
\text { OPG }\end{array}$ & $\begin{array}{l}1 d \\
1 d\end{array}$ & $\begin{array}{l}\text { No change at } 1 \mathrm{~h} \text { or } 168 \mathrm{~h} \\
\text { No change at } 1 \mathrm{~h} \text { or } 168 \mathrm{~h}\end{array}$ \\
\hline [1] Basaran 2006 & $\begin{array}{c}17 \\
17+-2\end{array}$ & $\begin{array}{l}0,7 d, 21 d, 6 m n s \\
\quad+7 d,+21 d\end{array}$ & Canine distalization & $\begin{array}{l}\text { IL-2 } \\
\text { IL-6 } \\
\text { IL-8 }\end{array}$ & & $\begin{array}{l}\text { Tend to increase at } 7 d \text {, back at } 21 d \\
\text { Tend to increase at } 7 d \text {, back at } 21 d \\
\text { Decrease at } 7 d \text {, back to baseline at } 21 d\end{array}$ \\
\hline [5] Giannopoulou 2006 & $\begin{array}{c}18 \\
9-14\end{array}$ & $0,1,24,168 \mathrm{~h}$ & Separation elastics & $\begin{array}{l}\text { IL-1 } 1 \beta \\
\mathrm{PGE}_{2}\end{array}$ & $1 d$ & $\begin{array}{l}\text { Associated with pain at } 24 \mathrm{~h} \\
\text { Weak association with pain at } 1 \mathrm{~h}\end{array}$ \\
\hline [27] Yamaguchi 2006 & $\begin{array}{c}9 \\
22-2\end{array}$ & $\begin{array}{c}0,1,4,8,24,72 \\
120,168 \mathrm{~h}\end{array}$ & Canine distalization & $\mathrm{IL}-1 \beta$ & $1 d$ & Correlated with P-substance \\
\hline [29] Toia 2005 & $\begin{array}{c}6 \\
10-13\end{array}$ & $0,4 \mathrm{~h}, 10 \mathrm{~d}$ & Aligning & IGF & $4 \mathrm{~h}$ & $\begin{array}{l}\text { Decreased } 10 \mathrm{~d} \text { after } \\
\text { time-dependent decrease }\end{array}$ \\
\hline [28] Hoshino-Itoh 2005 & $\begin{array}{c}10 \\
23+-3\end{array}$ & $0,1,24,168 \mathrm{~h}$ & Canine distalization & PAl & $1 d$ & $\begin{array}{l}\text { Increased only at } 24 \mathrm{~h} \\
\text { Increased only at } 24 \mathrm{~h}\end{array}$ \\
\hline [30] Iwasaki 2005 & $\begin{array}{c}10 \\
10-30\end{array}$ & $\begin{array}{l}-28,-14,0,1,3,14 \\
28,42,56,70,84 d\end{array}$ & Canine distalization & $\begin{array}{l}\text { IL-1 } 1 \beta \\
\text { IL-1ra }\end{array}$ & & $\begin{array}{l}\text { The ratio of both correlate with } \\
\text { the rate of tooth movement }\end{array}$ \\
\hline [6] Tuncer 2005 & $\begin{array}{c}10 \\
15-17\end{array}$ & $\begin{array}{l}0,1,24 \mathrm{~h}, 6 \mathrm{~d} \\
10 \mathrm{~d}, 30 \mathrm{~d}\end{array}$ & Canine distalization & IL-8 & & Tend to increase in early phase \\
\hline [31] Lee 2004 & $\begin{array}{c}10 \\
18-22\end{array}$ & $0,1,24,168 \mathrm{~h}$ & Canine distalization & $\begin{array}{l}\mathrm{IL}-1 \beta \\
\mathrm{PGE}_{2}\end{array}$ & $\begin{array}{l}1 d \\
1 d\end{array}$ & $\begin{array}{l}\text { Continuous: } 168 \mathrm{~h} \text { back to baseline } \\
\text { Interrupted: higher level at reactivation } \\
\text { Continuous: } 168 \mathrm{~h} \text { back to baseline } \\
\text { Interrupted: remained high for } 1 \mathrm{wk}\end{array}$ \\
\hline [32] Ren 2002 & $\begin{array}{c}43 \\
10-14 \\
41 \\
21-27\end{array}$ & $0,24 h$ & Aligning & $\begin{array}{l}\text { IL-6 } \\
\text { PGE }_{2}\end{array}$ & & $\begin{array}{l}\text { Upregulated in both age groups } \\
\text { Increased only in youngsters } \\
\text { Increased only in adults }\end{array}$ \\
\hline [33] Iwasaki 2001 & $\begin{array}{c}7 \\
12-16\end{array}$ & $\begin{array}{l}-28,-14,0,1,3,14 \\
28,42,56,70,84 d\end{array}$ & Canine distalization & $\begin{array}{l}\text { IL-1 } 1 \beta \\
\text { IL-1ra }\end{array}$ & & $\begin{array}{l}28 \mathrm{~d} \text { periodic changes, no site difference } \\
\text { No periodicity, no site difference }\end{array}$ \\
\hline
\end{tabular}


Table 1 (conclusion)

\begin{tabular}{|c|c|c|c|c|c|c|}
\hline Reference / Article & $\begin{array}{l}\text { Sample (n) } \\
\text { Age (yr) }\end{array}$ & Sampling (points) & Method & Cytokine & Peak & Results \\
\hline [2] Tzannetou 1999 & $\begin{array}{c}9 \\
10-18\end{array}$ & $0,24 h, 7 d, 14 d, 21 d$ & Hyrax RME & $\mathrm{IL}-1 \beta$ & & $\begin{array}{l}\text { Increased during active RME; } \\
\text { remained high in retention phase }\end{array}$ \\
\hline [34] Uematsu 1996 & $\begin{array}{l}12 \\
14\end{array}$ & $0,1,24,168 \mathrm{~h}$ & Canine distalization & $\begin{array}{c}\text { IL-1 } 1 \beta \\
\text { IL-6 } \\
\text { TNF- } \alpha\end{array}$ & $\begin{array}{l}1 d \\
1 d \\
1 d\end{array}$ & $\begin{array}{l}\text { No change at } 1 \mathrm{~h} \text { or } 168 \mathrm{~h} \\
\text { No change at } 1 \mathrm{~h} \text { or } 168 \mathrm{~h} \\
\text { No change at } 1 \mathrm{~h} \text { or } 168 \mathrm{~h} \\
\text { No change at } 1 \mathrm{~h} \text { or } 168 \mathrm{~h}\end{array}$ \\
\hline [37] Uematsu 1996 & $\begin{array}{l}12 \\
14\end{array}$ & $0,1,24,168 \mathrm{~h}$ & Canine distalization & TGF- $\beta 1$ & $1 d$ & No change at $1 \mathrm{~h}$ or $168 \mathrm{~h}$ \\
\hline [35] Lowney 1995 & $\begin{array}{c}20 \\
12-36\end{array}$ & $0,5 \mathrm{~min}$ & Canine distalization & TNF- $\alpha$ & & More than twofold increase \\
\hline [36] Grieve 1994 & $\begin{array}{c}10 \\
24-27\end{array}$ & $0,1,24,48,168 \mathrm{~h}$ & Aligning & $\begin{array}{l}\text { TNF- } \alpha \\
\text { PGE }\end{array}$ & $\begin{array}{l}1 d \\
1 d\end{array}$ & $\begin{array}{l}\text { Increased at } 1 \mathrm{~h} \text {, back to baseline at } 168 \mathrm{~h} \\
\text { Stay high at } 48 \mathrm{~h} \text {, back to baseline at } 168 \mathrm{~h}\end{array}$ \\
\hline
\end{tabular}

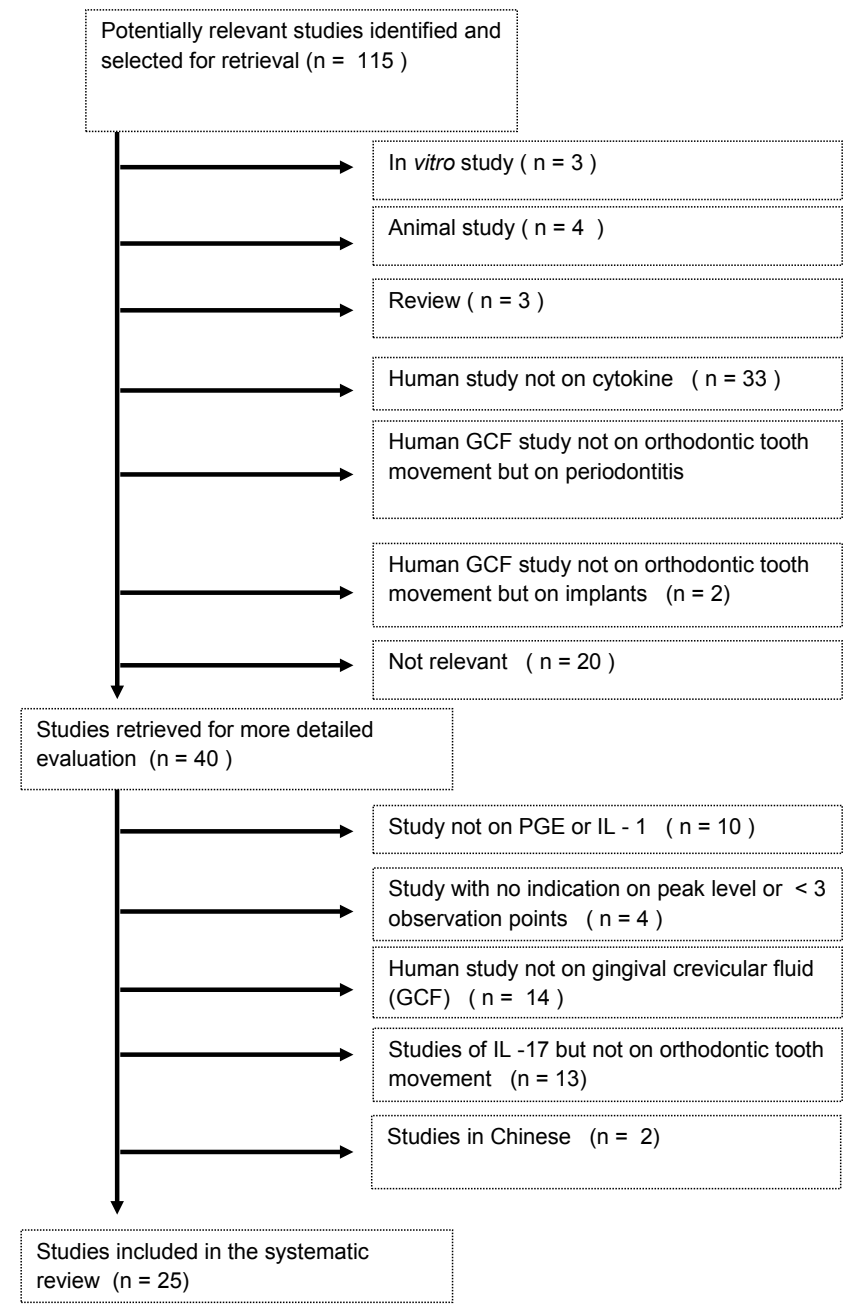

Figure 1. Flow chart of the literature search. The number of papers that were excluded from the review is listed in the right column.

The number of sampling time-points varied from study to study, and typically $1 \mathrm{~h}$ and 1 day $(1 \mathrm{~d})$ were included. When mesial-distal movement forces were applied, most studies sampled GCF only at pressure sides; otherwise, no discrimination was made between pressure or tension sides. Such discrimination was deemed necessary because different biological processes are involved on pressure and tension sides (bone resorption and bone formation, respectively). Three studies compared cytokine levels at pressure and tension sides, among which only one reported a significant difference (higher cytokine levels at the tension side).

Cytokine levels were up-regulated in most studies and many cytokines showed peaks at $1 \mathrm{~d}$, irrespective of treatment mechanics.

Significant heterogeneity was observed in the study design and report of data (Table 1), leading to the conclusion that a meta-analysis was not necessary. Also, not all known cytokines were investigated in such studies. Among the 25 studies, the most commonly studied cytokines were IL-1 $\beta(n=12)$, PGE $_{2}(n=5), T N F-\alpha(n=7)$, and IL-6 $(n=5)$ (Figure 1). Four studies $[23,30,32,42]$ had to be excluded from quantitative data synthesis because of insufficient relevant data or fewer than three observation time-points (Figure 1).

\section{DISCUSSION}

This systematic review analyzed studies on cytokines produced in GCF during orthodontic movement. Several cytokines have been analyzed in the literature, yet unfortunately there was great heterogeneity in study design and data reporting. Common failures were observed in clinical and laboratory studies during selection of papers for inclusion. Concerning the cytokine levels in GCF over time, the most consistent results were peak levels of the different cytokines at one day after application of orthodontic force, regardless of the treatment mechanics $[9,43]$.

Associations have been reported between pain intensity and GCF cytokine levels. Giannopoulou et al. [5] reported that simple routine procedures, such as placement of elastic separators, could cause pain in children. These authors reported fast release of biochemical markers $(1 \mathrm{~h})$ with peak after 1 day and partial decrease after 7 days. Similar outcomes were observed for the intensity of pain, which 
was associated with $\mathrm{PGE}_{2}$ levels at $1 \mathrm{~h}$, and with IL-1 $\beta$ levels at one day. Recently, Yamaguchi et al. (27) reported significant correlation between IL- $1 \beta$ and substance $P$, which is a peptide involved in pain and neurotransmission, during orthodontic treatment in adults, indirectly supporting an association between pain and IL-1 $\beta$ levels $[9,43]$.

With regard to the speed of tooth movement, Iwasaki et al. $[23,30,42]$ observed positive correlation with the IL-1ß: IL-1 receptor antagonist (IL-1) ratio.

Once all studies in this review included no use of antibiotic/anti-inflammatory drugs and proper oral hygiene control before the experiment, the contributory influence of gingivitis on the expression of cytokines in subjects of different ages could be eliminated. Following this same philosophy of strict oral hygiene, Dudic et al. [4] and Tzannetou $[2,3]$ concluded that the increased levels of biochemical markers did not seem to be associated with gingival inflammation. In the study of Dudic et al. [4], the levels of IL-1 $\beta$, SP and $\mathrm{PGE}_{2}$ were detected immediately after placement of separators. Amazingly, the levels of IL-1 $\beta, \mathrm{SP}$, and $\mathrm{PGE}_{2}$ were higher in tension compared to compression sites. These increased levels may reflect the biological activity that occurs during orthodontic movement. For instance, IL-1 $\beta$ has been shown as a very sensitive indicator of inflammation. This molecule is believed to be mainly secreted by macrophages. However, accumulation of macrophages in compression sites was observed at later stages, after initiation of tooth movement. Possibly, during the initial stage of orthodontic treatment, IL- $1 \beta$ is originated from other periodontal cell types, such as osteoclasts, as an immediate response to mechanical stress.

Data on IL-1 $\beta$ suggested that it is produced in response to different treatment mechanics. Lee et al. [31] compared the release of $\mathrm{PGE}_{2}$ and IL- $1 \beta$ in continuous and interrupted forces and reported that these regulatory proteins showed different responses, with less consistent changes in $\mathrm{PGE}_{2}$ levels with different force protocols than IL-1 $\beta$, and no evident response of $\mathrm{PGE}_{2}$ to re-activation. These results indicate that the mechanics may be a decisive factor regulating cytokine production, and also that different cytokines may respond differently to similar mechanics.

Considering the different patterns of expression of IL- $1 \beta$ and $\mathrm{PGE}_{2}$, it may be assumed that, in orthodontic tooth movement, force activation may initially trigger the production of IL-1 $\beta$. Thereafter, increased IL- $1 \beta$ levels combined with mechanical stress may combine to stimulate $\mathrm{PGE}_{2}$ production, as demonstrated by its rapid elevation and peak at $1 \mathrm{~d}$. Subsequently, extended up-regulation of $\mathrm{PGE}_{2}$ may trigger a feedback mechanism that decreases the IL-1 $\beta$ levels, which in turn promotes an even faster decrease in $\mathrm{PGE}_{2}$, irrespective of the sustained mechanical stress. Additionally, IL-1 $\beta$ also responded to the intensity of mechanics. Interleukin- $1 \beta$ levels displayed significant elevation between $1 \mathrm{~h}[4,5,36]$ and $1 \mathrm{~d}$. Peak of IL- $1 \beta$ was observed at $1 \mathrm{~d}[27,31,34], 72 \mathrm{~h}$ [35], or not at all [2]. Without re-activation, IL-1 $\beta$ decreased significantly at $7 \mathrm{~d}$ to the baseline level, yet reached a higher peak after re-activation [31].
Moreover, a heavy decaying force $[27,34]$ tended to significantly decrease the IL- $1 \beta$ level at $7 \mathrm{~d}$, suggesting the need for timely re-activation to keep sufficient IL-1 $\beta$ production [43]. Light continuous force [30,31,42] tended to maintain longer, relatively high IL-1 $\beta$ levels, allowing a reduced frequency of re-activations [43]. These results reveal important clinical implications for orthodontics and provide evidence for the utilization of light continuous force in orthodontics at the cellular level [44], since light continuous forces induce relatively longer lasting levels of cytokines, which are necessary for continuous periodontal remodeling. Heavy decaying force may increase the risk of root resorption and PDL hyalinization $[45,46]$, and may also tend to induce acute up-and-downs in cytokine levels, which may cause undesirable tissue reactions and need for more re-activations.

Many studies did not differentiate tension and pressure sides, or merely look samples at pressure sides. Studies sampling both sides did not reveal significant or consistent difference [6,23]. Only one study [4] reported higher levels of cytokine at the tension side at $1 \mathrm{~min}$ and $7 \mathrm{~d}$ after placement of separation elastics, yet this was not observed at $1 \mathrm{~h}$ and $1 \mathrm{~d}$. Thus, there may be no clear difference in cytokines in GCF samples collected at tension or pressure sites. This is probably related to the continuous circulation of GCF in the periodontal ligament, and is supported by finite element analyses revealing that compression and tension areas were only observed when the PDL was modeled as a linear material. So far, it may only be concluded that the levels of cytokine in GCF may not be specific indicators of periodontal remodeling at tension and pressure sites.

It has been suggested that the cellular response may be part of a generalized increase in metabolic activity, rather than a response to mechanical strain [4]. Also, there is great difficulty in understanding cytokine biology due to the number and complexity of these factors, besides their overlapping activities and multiple biological effects $[1,10,11,47]$. Thus, only analysis of a group of regulatory proteins may indicate an organized and complex cascade of cytokine-related cellular activities during treatment $[13,48]$. Both the up-regulation of some cytokines and their specificity to orthodontic movements should be carefully interpreted.

\section{CONCLUSION}

This systematic review leads to the following conclusions:

1. Application of orthodontic forces causes release of inflammatory bone-resorptive mediators at $1 \mathrm{~h}$ that reach peak at 1 day.

2. The cytokines levels decrease after attaining peak values, mostly at 1 day.

3. A rise in GCF levels of IL-1 $\beta$ has been linked to increased pain intensity during orthodontic movement.

The present results revealed that light continuous forces tended to maintain relatively high IL-1 $\beta$ levels for longer periods, which is necessary for continuous periodontal 
remodeling and to reduce the frequency of re-activations. Additionally, GCF studies have the advantage of being noninvasive and allowing analysis of diagnosis and prognosis. However, there is significant heterogeneity in published papers as to the sample size, age, study periods, duration of observations, and mechanisms employed. Therefore, future studies should enhance the GCF sampling and measuring protocols, addressing the relationship between cytokine production and force re-activations and the expression of cytokine receptors, in order to better illustrate the high potential of GCF as a diagnostic tool to control the clinical outcome in orthodontics.

\section{REFERENCES}

1. Basaran G, Ozer T, Kaya FA, Hamamci O. Interleukins 2, 6, and 8 levels in human gingival sulcus during orthodontic treatment. Am J Orthod Dentofacial Orthop. 2006;130(1):7 e1-6.

2. Tzannetou S, Efstratiadis S, Nicolay O, Grbic J, Lamster I. Interleukin-1 $\beta$ and $\beta$-Glucuronidase in gingival crevicular fluid from molars during rapid palatal expansion. Am J Orthod Dentofacial Orthop. 1999;115(6):686-96. https://doi.org/10.1016/S0889-5406(99)70295-7

3. Tzannetou S, Efstratiadis S, Nicolay O, Grbic J, Lamster I. Comparison of levels of inflammatory mediators IL-1beta and betaG in gingival crevicular fluid from molars, premolars, and incisors during rapid palatal expansion. Am J Orthod Dentofacial Orthop. 2008;133(5):699-707. https://doi. org/10.1016/j.ajodo.2006.03.044

4. Dudic A, Kiliaridis S, Mombelli A, Giannopoulou C. Composition changes in gingival crevicular fluid during orthodontic tooth movement: comparisons between tension and compression sides. Eur J Oral Sci. 2006;114(5): 416-22. https://doi.org/10.1111/j.1600-0722.2006.00387.x

5. Giannopoulou C, Dudic A, Kiliaridis S. Pain discomfort and crevicular fluid changes induced by orthodontic elastic separators in children. J Pain. 2006;7(5):367-76. https://doi.org/10.1016/j.jpain.2005.12.008

6. Tuncer BB, Ozmeric N, Tuncer C, Teoman I, Cakilci B, Yucel A, et al Levels of interleukin-8 during tooth movement. Angle Orthod. 2005;75(4): 631-6.

7. Madureira DF, Taddei SA, Abreu MHNG, Pretti H, Lages EMB, Silva TA Kinetics of interleukin- 6 and chemokine ligands 2 and 3 expression of periodontal tissues during orthodontic tooth movement. Am J Orthod Dentofacial Orthop. 2012;142(4):494-500. https://doi.org/10.1016/j. ajodo.2012.05.012

8. Griffiths GS. Formation, collection and significance of gingival crevice fluid. Periodontol. 2003;31(1):32-42. https://doi.org/10.1034/j.16000757.2003.03103.x

9. Ren $Y$, Vissink A. Cytokines in crevicular fluid and orthodontic tooth movement. Eur J Oral Sci. 2008;116(2):89-97. https://doi.org/10.1111/ j.1600-0722.2007.00511.x

10. Ouyang W, Kolls JK, Zheng Y. The biological functions of T helper 17 cell effector cytokines in inflammation. Immunity. 2008;28(4):454-67. https:// doi.org/10.1016/j.immuni.2008.03.004

11. McKenzie BS, Kastelein RA, Cua DJ. Understanding the IL-23-IL-17 immune pathway. Trends in Immunol. 2006;27(1):17-23. https://doi. org/10.1016/j.it.2005.10.003

12. Maloy KJ. The Interleukin-23/Interleukin-17 axis in intestinal inflammation. J Intern Med. 2008;263(6):584-90. https://doi.org/10.1111/j.13652796.2008.01950.x

13. Tan ZY, Bealgey KW, Fang Y, Gong YM, Bao S. Interleukin-23: immunological roles and clinical implications. Intern J Biochem Cell Biol. 2009;41(4): 733-5. https://doi.org/10.1016/j.biocel.2008.04.027

14. Cheng W-C, Hughes FJ, Taams LS. The presence, function and regulation of IL-17 and Th17 cells in periodontitis. J Clin Periodontol. 2014;41(6): 541-9. https://doi.org/10.1111/jcpe.12238

15. Nakao K, Goto T, Gunjigake KK, Konoo T, Kobayashi S, Yamaguchi K. Intermittent force induces high RANKL expression in human periodontal ligament cells. J Dent Res. 2007;86(7):623-8. https://doi. org/10.1177/154405910708600708

16. d'Apuzzo F, Cappabianca S, Ciavarella D, Monsurro A, Silvestrini-Biavati A, Perillo L. Biomarkers of periodontal tissue remodeling during orthodontic tooth movement in mice and men: overview and clinical relevance. Scientific World Journal. 2013;2013:1-8. https://doi.org/10.1155/2013/ 105873
17. Salminen A, Gursoy UK, Paju S, Hyvärinen K, Mäntylä P, Buhlin K, et al. Salivary biomarkers of bacterial burden, inflammatory response, and tissue destruction in periodontitis. J Clin Periodontol. 2014;41(5):442-50. https://doi.org/10.1111/jcpe.12234

18. Park YD, Kim YS, Jung YM, Lee SI, Lee YM, Bang JB, et al. Porphyromonas gingivalis lipopolysaccharide regulates interleukin (IL)-17 and IL-23 expression via SIRT1 modulation in human periodontal ligament cells. Cytokine. 2012;60(1):284-93. https://doi.org/10.1016/j.cyto.2012.05.021

19. Sánchez GA, Miozza VA, Delgado A, Busch L. Salivary IL-1 $\beta$ and PGE2 as biomarkers of periodontal status, before and after periodontal treatment. J Clin Periodontol. 2013;40(12):1112-7. https://doi.org/10.1111/jcpe.12164

20. Olivier BJ, Schoenmaker T, Mebius RE, Everts V, Mulder CJ, van Nieuwkerk $\mathrm{KMJ}$, et al. Increased osteoclast formation and activity by peripheral blood mononuclear cells in chronic liver disease patients with osteopenia. Hepatology. 2008;47(1):259-67. https://doi.org/10.1002/hep.21971

21. Turpin DL. CONSORT and QUOROM guidelines for reporting randomized clinical trials and systematic reviews. Am J Orthod Dentofacial Orthop. 2005;128(6):681-5. https://doi.org/10.1016/j.ajodo.2005.10.010

22. Karacay S, Saygun I, Bengi AO, Serdar M. Tumor Necrosis Factor- $\alpha$ Levels during Two Different Canine Distalization Techniques. The Angle Orthodontist. 2007;77(1):142-7. https://doi.org/10.2319/120905-430R.1

23. Iwasaki LR, Gibson CS, Crouch LD, Marx DB, Pandey JP, Nickel JC. Speed of tooth movement is related to stress and IL-1 gene polymorphisms. Am J Orthod Dentofacial Orthop. 2006;130(6):698 e1-9.

24. Basaran G, Ozer T, Kaya FA, Kaplan A, Hamamci O. Interleukine-1beta and tumor necrosis factor-alpha levels in the human gingival sulcus during orthodontic treatment. Angle Orthod. 2006;76(5):830-6.

25. Kawasaki K, Takahashi T, Yamaguchi M, Kasai K. Effects of aging on RANKL and OPG levels in gingival crevicular fluid during orthodontic tooth movement. Orthod Craniofac Res. 2006;9(3):137-42. https://doi. org/10.1111/j.1601-6343.2006.00368.x

26. Nishijima Y, Yamaguchi M, Kojima T, Aihara N, Nakajima R, Kasai K. Levels of RANKL and OPG in gingival crevicular fluid during orthodontic tooth movement and effect of compression force on releases from periodontal ligament cells in vitro. Orthod Craniofac Res. 2006;9(2):63-70. https://doi. org/10.1111/j.1601-6343.2006.00340.x

27. Yamaguchi M, Yoshii M, Kasai K. Relationship between substance P and interleukin-1beta in gingival crevicular fluid during orthodontic tooth movement in adults. Eur J Orthod. 2006;28(3):241-6. https://doi. org/10.1093/ejo/cji100

28. Hoshino-Itoh J, Kurokawa A, Yamaguchi M, Kasai K. Levels of t-PA and $\mathrm{PAl}-2$ in gingival crevicular fluid during orthodontic tooth movement in adults. Aust Orthod J. 2005;21(1):31-7.

29. Toia M, Galazzo R, Maioli C, Granata R, Scarlatti F. The IGF-I/IGFBP-3 system in gingival crevicular fluid and dependence on application of fixed force. J Endocrinol Invest. 2005;28(11):1009-14. https://doi.org/10.1007/ BF03345340

30. Iwasaki LR, Crouch LD, Tutor A, Gibson S, Hukmani N, Marx DB, et al Tooth movement and cytokines in gingival crevicular fluid and whole blood in growing and adult subjects. Am J Orthod Dentofacial Orthop. 2005;128(4):483-91. https://doi.org/10.1016/j.ajodo.2004.03.037

31. Lee KJ, Park YC, Yu HS, Choi SH, Yoo YJ. Effects of continuous and interrupted orthodontic force on interleukin-1beta and prostaglandin E2 production in gingival crevicular fluid. Am J Orthod Dentofacial Orthop. 2004;125(2):168-77. https://doi.org/10.1016/j.ajodo.2003.03.006

32. Ren Y, Maltha JC, Van't Hof MA, Von Den Hoff JW, Kuijpers-Jagtman AM, Zhang D. Cytokine levels in crevicular fluid are less responsive to orthodontic force in adults than in juveniles. J Clin Periodontol. 2002;29(8):757-62. https://doi.org/10.1034/j.1600-051X.2002.290813.x

33. Iwasaki LR, Haack JE, Nickel JC, Reinhardt RA, Petro TM. Human interleukin-1 beta and interleukin-1 receptor antagonist secretion and velocity of tooth movement. Arch Oral Biol. 2001;46(2):185-9. https://doi. org/10.1016/S0003-9969(00)00088-1

34. Uematsu S, Mogi M, Deguchi T. Interleukin (IL)-1 beta, IL-6, tumor necrosis factor-alpha, epidermal growth factor, and beta 2-microglobulin levels are elevated in gingival crevicular fluid during human orthodontic tooth movement. J Dent Res. 1996;75(1):562-7. https://doi.org/10.1177/00220 345960750010801

35. Lowney JJ, Norton LA, Shafer DM, Rossomando EF. Orthodontic forces increase tumor necrosis factor $\alpha$ in the human gingival sulcus. Am J Orthod Dentofacial Orthop. 1995;108(5):519-24. https://doi.org/10.1016/ S0889-5406(95)70052-8

36. Grieve WG, 3rd, Johnson GK, Moore RN, Reinhardt RA, DuBois LM. Prostaglandin E (PGE) and interleukin-1 beta (IL-1 beta) levels in gingival crevicular fluid during human orthodontic tooth movement. Am J Orthod Dentofacial Orthop. 1994;105(4):369-74. https://doi.org/10.1016/S08895406(94)70131-8 
37. Uematsu S, Mogi M, Deguchi T. Increase of transforming growth factor- $\beta 1$ in gingival crevicular fluid during human orthodontic tooth movement. Arch Oral Biol. 1996;41(11):1091-5. https://doi.org/10.1016/S00039969(96)00063-5

38. Tian YL, Xie JC, Zhao ZJ, Zhang Y. Changes of interlukin-1beta and tumor necrosis factor-alpha levels in gingival crevicular fluid during orthodontic tooth movement. Hua Xi Kou Qiang Yi Xue Za Zhi. 2006;24(3):243-5.

39. van Gastel J, Teughels W, Quirynen M, Struyf S, Van Damme J, Coucke $W$, et al. Longitudinal changes in gingival crevicular fluid after placement of fixed orthodontic appliances. Am J Orthod Dentofacial Orthop. 2011;139(6):735-44. https://doi.org/10.1016/j.ajodo.2009.10.043

40. Enhos S, Veli I, Cakmak O, Ucar FI, Alkan A, Uysal T. OPG and RANKL levels around miniscrew implants during orthodontic tooth movement. Am J Orthod Dentofacial Orthop. 2013;144(2):203-9. https://doi.org/10.1016/j. ajodo.2013.02.028

41. Alikhani M, Raptis M, Zoldan B, Sangsuwon C, Lee YB, Alyami B, et al. Effect of micro-osteoperforations on the rate of tooth movement. Am J Orthod Dentofacial Orthop. 2013;144(5):639-48. https://doi.org/10.1016/j. ajodo.2013.06.017

42. Iwasaki LR, Haack JE, Nickel JC, Reinhardt RA, Petro TM. Human interleukin-1 $\beta$ and interleukin-1 receptor antagonist secretion and velocity of tooth movement. Arch Oral Biol. 2001;46(2):185-9. https://doi. org/10.1016/S0003-9969(00)00088-1

43. Kapoor P, Kharbanda OP, Monga N, Miglani R, Kapila S. Effect of orthodontic forces on cytokine and receptor levels in gingival crevicular fluid: a systematic review. Prog Orthod. 2014;15(65):1-21. https://doi. org/10.1186/s40510-014-0065-6

44. Ren Y, Maltha JC, Kuijpers-Jagtman AM. Optimum Force Magnitude for Orthodontic Tooth Movement: A Systematic Literature Review. Angle Orthod. 2003;73(1):86-92

45. Maltha JC, van Leeuwen EJ, Dijkman G, Kuijpers-Jagtman AM. Incidence and severity of root resorption in orthodontically moved premolars in dogs. Orthod Craniofac Res. 2004;7(2):115-21. https://doi.org/10.1111/j.16016343.2004.00283.x

46. Böhl Mv, Maltha JC, Von Den Hoff JW, Kuijpers-Jagtman AM. Focal hyalinization during experimental tooth movement in beagle dogs. Am J Orthod Dentofacial Orthop. 2004;125(5):615-23. https://doi.org/10.1016/j. ajodo.2003.08.023

47. Pappu BP, Angkasekwinai P, Dong C. Regulatory mechanisms of helpe $T$ cell differentiation: new lessons learned from interleukin 17 family cytokines. Pharmacol Ther.. 2008;117(3):374-84. https://doi.org/10.1016/j. pharmthera.2007.12.003

48. Iwasaki LR, Chandler JR, Marx DB, Pandey JP, Nickel JC. IL-1 gene polymorphisms, secretion in gingival crevicular fluid, and speed of human orthodontic tooth movement. Orthod Craniofac Res. 2009;12(2):129-40. https://doi.org/10.1111/j.1601-6343.2009.01446.x 